\title{
A DESCRIPTIVE STUDY TO ASSESS THE KNOWLEDGE AND PRACTICE RELATED TO BREAST FEEDING AMONG PRIMI POSTNATAL MOTHERS IN MAHILA CHIKITSALAYA, JAIPUR
}

\author{
Annamma Sumon \\ Nursing Tutor, Govt. College of Nursing Jodhpur, Rajasthan
}

Article DOI: https://doi.org/10.36713/epra7969

DOI No: 10.36713/epra7969

\begin{abstract}
INTRODUCTION: Children bring fragrance and meaning to life. They are a gift to us from God and we are the gardeners to meet their needs. We can provide the best to them by proper nourishments, love, attention, care and good health. Today's children are citizen of tomorrow and to have a strong-shouldered man a child should be free from morbidity. Mahler, who was the Director General of the W.H.O. in 1984, stated that "children are a priceless resource and a nation which neglects them does so at its peril". Healthy children are the greatest resource and pride of the nation; the children ought to be healthy and happy to become productive adults of the future. To give them a happy and healthy childhood, we must safeguard their total health right from the beginning.

AIM OF THE STUDY: Assess the knowledge and practice related to breast feeding among primi postnatal mothers. MATERIAL AND METHOD: A descriptive study was carried out to assess the knowledge and practice of 100 primi postnatal mothers selected by purposive sampling, in Mahila Chikitsalaya, Jaipur (Rajasthan) and were assessed by using a structured knowledge questionnaire and analyzed by using descriptive and inferential statistics for data analysis.

RESULT: The findings of the study reveals that the level of knowledge shows that majority (43\%) of the sample had moderate knowledge regarding breast feeding and (46\%) had moderate practice of breast feeding. However, the majority of the demographic variables such as age, religion, educational status, occupation, monthly income, place of residence, source of information and number of antenatal visits were significantly associated with knowledge of primi postnatal mothers regarding breast feeding and selected demographic variables is accepted. Variables such as age, religion, educational status, occupation, monthly income, place of residence and number of antenatal visits were significantly associated with practices of primi postnatal mothers regarding breast feeding and selected demographic variables is accepted.

CONCLUSION: It can be concluded that primi postnatal mothers have moderate knowledge and practice regarding breast feeding as per current research recommendations.

KEY WORDS: Knowledge, Practice, Primi Postnatal mothers, Breast feeding.
\end{abstract}

\section{INTRODUCTION \& BACKGROUND OF THE STUDY}

Breast feeding SAVES LIVES by providing a complete nutritional \& preventive health package for infants and young children, and is one of the most sustainable practices found on this earth. Breastfeeding may be the single most important thing a mother can do for the health of her infant in the first year of life. For most of the world's children, exclusive breast-feeding makes the difference between life and death and it is the infant's "passport to life". A breast fed baby enjoys not only the comfort of warm breast but with all her senses she drinks in her mother's love. Breast feeding applies to each of the Millennium Development Goals \& can have a large impact on the future well-being of our society.

In India only $20 \%$ women are able to practice exclusive breastfeeding for six months. Extending 


\section{EPRA International Journal of Research and Development (IJRD) Volume: 6 | Issue: 7 | July 2021 \\ - Peer Reviewed Journal}

coverage of exclusive breastfeeding and complementary feeding could save over 450,000 child deaths each year in India (IYCF report-2012). Instead of promoting exclusive breastfeeding immediately after birth, there are various hindrance which prevent such practice in India i.e., $48.1 \%$ mothers do not feed because they feel that milk is not available, $39.6 \%$ followed family traditional advices, $10.4 \%$ mothers were uncomfortable in feeding \& others were not advised by hospitals staff due to $\mathrm{C}$-section delivery.

Breast milk is a natural resource that is too valuable to lose; to ignore it is to promote mortality, suffering, personal, national and economic stress. The scientific literature reviewed recently for policy makers shows that breast-feeding can save more infant lives and prevent more morbidity than any other interventional strategy. Currently breast-feeding saves six million infant lives each year by preventing diarrhoea and acute respiratory infections. This alone is responsible for one forth to one third of the observed fertility suppression and can provide high quality nutrition at a fraction of the cost of artificial feeding.

From the observation in the postnatal ward \& real life experience the researcher found that the primi mothers were not aware of the facts regarding breast feeding of their infants. So, the researcher is interested to identify the knowledge and practice of primi mothers about breast-feeding. The variable that may be modifiable includes knowledge and practice of the mothers and these are the important determinants of maternal breast feeding method. The present study aims at assessing the knowledge and practice of mothers regarding breast feeding.

\section{OBJECTIVES OF THE STUDY}

- To assess the knowledge of primi post-natal mothers regarding breast feeding.

- To assess the practice of primi post-natal mothers regarding breast feeding.

- To find out the association between knowledge of mothers with selected demographic variables.

- To find out the association between practice of mothers with selected demographic variables.

- $\quad$ To find the co-relation between knowledge \& practice.

\section{HYPOTHESIS OF THE STUDY}

- $\quad \mathbf{H}_{1}$ - There will be a significant association between demographic variables \& knowledge $\&$ practice score of primi post-natal mothers regarding breast feeding.

- $\quad \mathbf{H}_{\mathbf{0 1}}$ - There will not be a significant association between demographic variables \& knowledge $\&$ practice score of primi post-natal mothers regarding breast feeding.
- $\quad \mathbf{H}_{2-}$ There will be a significant relationship between knowledge \& practice score of primi post-natal mothers regarding breast feeding.

- $\mathbf{H}_{\mathbf{0 2}^{-}}$There will not be a significant relationship between knowledge \& practice score of primi post-natal mothers regarding breast feeding.

\section{OPERATIONAL DEFINITION}

- Descriptive study - In this study it refers to give brief description of knowledge and practice regarding breast-feeding.

- Assess- In this study it refers to identify the knowledge \& practice of primi postnatal mothers regarding breast feeding.

- Knowledge - It is the correct response of the mother to the knowledge items regarding breast feeding, initiation of breast-feeding, advantages of breast-feeding, duration of breast-feeding and diet during breast-feeding which is measured by questionnaire.

- Practice - Verbal responses of the mothers to practice items related to breast-feeding which is measured by check list.

- Breast-feeding - It refers to feed the baby from the mother's breast.

- Primi postnatal mother- Primi Postnatal mother is the one who has given birth for the first time.

\section{ASSUMPTION}

- Primi postnatal mothers have inadequate knowledge regarding breast feeding

- Primi postnatal mothers are not aware of proper techniques of breast feeding.

- Postnatal mothers will vary in breast feeding practices according to socio cultural factors.

- Primi paras are having less knowledge regarding breast feeding than multiparas.

- Primi postnatal mothers will co-operate in the study.

\section{DELIMITATION}

- Sample size is delimited to 100 primi postnatal mothers.

- The study is delimited to the primi postnatal mothers admitted in Mahila Chikitsalaya, Jaipur.

- $\quad$ Primi post-natal mothers of age 18-34 years.

- Primi post-natal mothers who are available during the period of data collection $\&$ are willing to participate in the study.

- Primi post-natal mothers who had normal vaginal delivery and have started breast feeding. 


\section{EPRA International Journal of Research and Development (IJRD)

\section{RESEARCH METHODOLOGY}

- RESEARCH APPROACH

Quantitative research approach is considered appropriate for the present study.

\section{- RESEARCH DESIGN}

Descriptive survey design was adopted for this study.

\section{RESEARCH VARIABLE}

- Research variable

Research variables are those variables which are observed and measured in natural setting as they exist without any manipulation in the descriptive study, no cause effect relationship is examined. In my study the research variables is Knowledge and practices related to breastfeeding.

\section{- Demographic variable}

Demographic variables are the characteristics and attributes of the study sample. In my study the demographic variables are age, religion, education of the participant, occupation of the participant, monthly income, type of family, place of residence, and source of information.

\section{POPULATION}

Primi post-natal mothers who are admitted in post-natal wards after having normal vaginal delivery $\&$ has initiated breast feeding practices.

\section{SAMPLE SIZE}

In this study, the sample consists of 100 primi post-natal mothers who are admitted in post-natal ward of Mahila Chikitsalaya, after normal vaginal delivery \& has initiated breast feeding practices.

\section{SAMPLING TECHNIQUE}

Non-probability purposive sampling technique was used for this study.

\section{RELIABLITY OF THE TOOL}

The correlation was found by using Karl Pearson's correlation co-efficient. The reliability coefficient of the whole tool was then estimated by Spearman Brown prophecy formula. The tool was found reliable $(\mathrm{r}=$ $0.86)$.

\section{MAJOR FINDING OF THE STUDY}

Table 1 Depicted that of primi post-natal mothers participated in the study, Age group 18-22 years (61, 61\%), Religion Hindu (88, 88\%), Educational status Primary Education (29, 29\%), Occupation Housewife (73, 73\%), Monthly Income Less than Rs. 5000 (41, 41\%), Family type Joint family $(82,82 \%)$, Place of residence Urban $(60,60 \%)$, Source of information Family members and relatives (71, $71 \%$ ), Number of antenatal visits done Three (44, $44 \%$ ), and Duration after the delivery, the baby was given to her After 3-4 hours (74, 74\%).

Table 2 Depicted that the majority $43 \%$ of the subjects had moderate knowledge and $29 \%$ had inadequate knowledge and $28 \%$ of them had adequate knowledge regarding breast feeding.

Table 3 Depicts that the majority $45 \%$ of the subjects had poor practice, $46 \%$ had moderately good practice of breast feeding. Only $9 \%$ of the subjects had good breast feeding practice.

Table 4 Depicts that the overall mean percentage of knowledge score was $64.29 \%$ with the standard deviation of 4.814 and the mean percentage of practice score was 73.54 with the standard deviation of 2.026 .

Table 1. Frequency and percentage distribution of demographic variables among primi post-natal mothers.

\begin{tabular}{|c|c|c|c|c|}
\hline \multirow{3}{*}{$\begin{array}{r}\text { S. No } \\
1 .\end{array}$} & & & \multicolumn{2}{|c|}{$(N=100)$} \\
\hline & \multicolumn{2}{|c|}{ Socio-demographic variable } & Frequency & Percentage \\
\hline & Age group & $\begin{array}{l}18-22 \text { years } \\
22-26 \text { years } \\
26-30 \text { years }\end{array}$ & $\begin{array}{l}61 \\
29 \\
10\end{array}$ & $\begin{array}{l}61 \% \\
29 \% \\
10 \%\end{array}$ \\
\hline 2. & Religion & $\begin{array}{r}\text { Hindu } \\
\text { Muslim } \\
\end{array}$ & $\begin{array}{l}88 \\
12 \\
\end{array}$ & $\begin{array}{l}88 \% \\
12 \% \\
\end{array}$ \\
\hline 3. & Educational status & $\begin{array}{c}\text { Uneducated } \\
\text { Primary Education } \\
\text { Secondary education } \\
\text { Senior secondary education } \\
\text { Graduation and above }\end{array}$ & $\begin{array}{c}8 \\
29 \\
22 \\
15 \\
26\end{array}$ & $\begin{array}{l}8 \% \\
29 \% \\
22 \% \\
15 \% \\
26 \%\end{array}$ \\
\hline 4. & Occupation & $\begin{array}{c}\text { Housewife } \\
\text { Service } \\
\text { Labour } \\
\end{array}$ & $\begin{array}{l}73 \\
13 \\
14 \\
\end{array}$ & $\begin{array}{l}73 \% \\
13 \% \\
14 \%\end{array}$ \\
\hline 5. & Monthly Income & $\begin{array}{l}\text { Less than Rs. } 5000 \\
\text { Rs. 5001-10000 }\end{array}$ & $\begin{array}{l}41 \\
40\end{array}$ & $\begin{array}{l}41 \% \\
40 \%\end{array}$ \\
\hline
\end{tabular}


EPRA International Journal of Research and Development (IJRD) Volume: 6 | Issue: 7 | July 2021

- Peer Reviewed Journal

\begin{tabular}{|c|c|c|c|c|}
\hline & & More than Rs. 10001 & 19 & $19 \%$ \\
\hline 6. & Family type & $\begin{array}{c}\text { Nuclear family } \\
\text { Joint family }\end{array}$ & $\begin{array}{l}18 \\
82\end{array}$ & $\begin{array}{l}18 \% \\
82 \% \\
\end{array}$ \\
\hline 7. & Place of residence & $\begin{array}{l}\text { Urban } \\
\text { Rural }\end{array}$ & $\begin{array}{l}60 \\
40\end{array}$ & $\begin{array}{l}60 \% \\
40 \%\end{array}$ \\
\hline 8. & Source of information & $\begin{array}{c}\text { Family members and relatives } \\
\text { Friends } \\
\text { Health Personnel } \\
\text { Others } \\
\end{array}$ & $\begin{array}{c}71 \\
9 \\
12 \\
8 \\
\end{array}$ & $\begin{array}{l}71 \% \\
9 \% \\
12 \% \\
8 \% \\
\end{array}$ \\
\hline 9. & $\begin{array}{l}\text { Number of antenatal visits } \\
\text { done }\end{array}$ & $\begin{array}{l}\text { Two } \\
\text { Three } \\
\text { None }\end{array}$ & $\begin{array}{l}36 \\
44 \\
20\end{array}$ & $\begin{array}{l}36 \% \\
44 \% \\
20 \%\end{array}$ \\
\hline 10. & $\begin{array}{c}\text { Duration after the } \\
\text { delivery, the baby was } \\
\text { given to her }\end{array}$ & $\begin{array}{l}\text { Within one hour } \\
\text { After 3-4 hours }\end{array}$ & $\begin{array}{l}26 \\
74\end{array}$ & $\begin{array}{l}26 \% \\
74 \%\end{array}$ \\
\hline
\end{tabular}

Table 2. Knowledge of primi post-natal mothers regarding breast feeding $(\mathrm{N}=100)$

\begin{tabular}{|c|c|c|}
\hline Level of Knowledge & Frequency & Percentage \\
\hline Inadequate knowledge & 29 & $29 \%$ \\
\hline Moderate knowledge & 43 & $23 \%$ \\
\hline Adequate knowledge & 28 & $\mathbf{1 0 0}$ \\
\hline Total & $\mathbf{1 0 0}$ & $28 \%$ \\
\hline
\end{tabular}

Table 3. Practice of primi post-natal mothers regarding breast feeding $(\mathrm{N}=100)$

\begin{tabular}{|c|c|c|}
\hline Level of Practice & Frequency & Percentage \\
\hline Poor practice & 45 & $45 \%$ \\
\hline Moderately good practice & 46 & $46 \%$ \\
\hline Good practice & 9 & $9 \%$ \\
\hline Total & $\mathbf{1 0 0}$ & $\mathbf{1 0 0}$ \\
\hline
\end{tabular}

Table 4. Mean, Mean percentage and Standard Deviation for the knowledge and practice scores of primi

\begin{tabular}{|c|c|c|c|c|c|c|c|}
\hline \multicolumn{8}{|c|}{ postnatal mothers $(\mathrm{N}=100)$} \\
\hline $\begin{array}{l}\text { S. } \\
\text { No. }\end{array}$ & Knowledge aspects & $\begin{array}{l}\text { No. of } \\
\text { Items }\end{array}$ & $\begin{array}{c}\text { Max } \\
\text { Score }\end{array}$ & Mean & Mean\% & Median & SD \\
\hline 1 & $\begin{array}{l}\text { General knowledge regarding } \\
\text { breast feeding }\end{array}$ & 5 & 5 & 2.93 & 58.6 & 3 & 1.343 \\
\hline 2 & Initiation of breast feeding & 5 & 5 & 3.22 & 64.4 & 3 & 1.353 \\
\hline 3 & Advantages of breast feeding & 3 & 3 & 2.03 & 67.66 & 2 & 0.745 \\
\hline 4 & Duration of breast feeding & 4 & 4 & 2.11 & 52.75 & 2 & 1.302 \\
\hline 5 & Technique of breast feeding & 5 & 5 & 3.47 & 69.4 & 4 & 1.068 \\
\hline 6 & $\begin{array}{l}\text { Diet during breast feeding for } \\
\text { mother }\end{array}$ & 2 & 2 & 1.67 & 83.5 & 2 & 0.533 \\
\hline & Overall Knowledge & 24 & 24 & 15.43 & 64.29 & 15.5 & 4.814 \\
\hline & Practice scores & 11 & 11 & 8.09 & 73.54 & 7.5 & 2.026 \\
\hline
\end{tabular}

\section{DISCUSSION}

The finding of the study shows that majority $43 \%$ of the subjects had moderate knowledge and $29 \%$ had inadequate knowledge and $28 \%$ of them had adequate knowledge regarding breast feeding.
Followed by $45 \%$ of the subjects had poor practice, $46 \%$ had moderately good practice of breast feeding. Only $9 \%$ of the subjects had good breast feeding practice. The overall mean percentage of knowledge score was $64.29 \%$ with the standard deviation of 4.814 


\section{EPRA International Journal of Research and Development (IJRD)

and the mean percentage of practice score was 73.54 with the standard deviation of 2.026. The obtained Pearson's correlation value 0.718 indicates the high positive correlation between the knowledge and practice of primi postnatal mothers regarding breast feeding. Hence the hypothesis stated that there will be significant correlation between the knowledge and practice of primi post-natal mothers regarding the breast feeding is accepted.

\section{CONCLUSION}

The finding raised concerns about all aspects of breast feeding. A considerable moderate knowledge regarding breastfeeding and moderate practices of breastfeeding. However, the majority of the demographic variables such as age, religion, educational status, occupation, monthly income, place of residence, source of information and number of antenatal visits were significant at 0.05 level. Therefore the hypothesis stated there will be significant association between knowledge of primi post-natal mothers regarding breast feeding and selected demographic variables is accepted. Variables such as age, religion, educational status, occupation, monthly income, place of residence and number of antenatal visits were significant at 0.05 levels. Therefore the hypothesis stated there will be significant association between practices of primi postnatal mothers regarding breast feeding and selected demographic variables is accepted.

\section{REFERENCES}

1. Alikasifoglu M., et al., 2001Factors influencing the duration of exclusive breastfeeding in a group of Turkish Women, J Hum Lact, , 17 ( 3 ) : 220 -226.

2. American Academy of Pediatrics, 1997, Breast Feeding and the Use of Human Milk Pediatrics, 100:1035-1039.

3. Arun Gupta et al., 2001.Breast feeding and complementary feeding, BPNI Publication: Delhi,

4. Barton SJ. 2001, "Infant feeding practices of lowincome rural mothers at rural Southeastern Kentucky".

5. Bennett, Ruth V and Linda K Brown, 1999 Myles Textbook for Midwives,Edinburgh: Churchill Livinstone, , pp590, 689,712-717.

6. Best,John $w$ and Kahn James v., 1999 Research in Education,Prentice-Hall of India Pvt. Ltd.: New Delhi, ,pp. 81.

7. Burns,Nancy and Grove Susan K., 1997, The Practice of Nursing Research-Methods, Appraisal and Utilization, W.B.Saunder's Compay :Tokyo, 790-796pp.

8. Chandra, Promotion of Breast feeding, Elbs Publication: Delhi, (2004).

9. Charles, $O$ Eregie, 1997 Observations on Certain Factors Associated With Exclusive Breast Feeding, International Child Health, ,8:45-50.

10. Das D.K, et al., 2000, The Knowledge and attitude of the mothers regarding breast feeding, J Trop Pediatric 48(4): 195-9
11. Dewan $N$ et al.,2002., Breast feeding knowledge and attitudes of teenage mothers in liver pool, Diet15(1) 33 - 7 